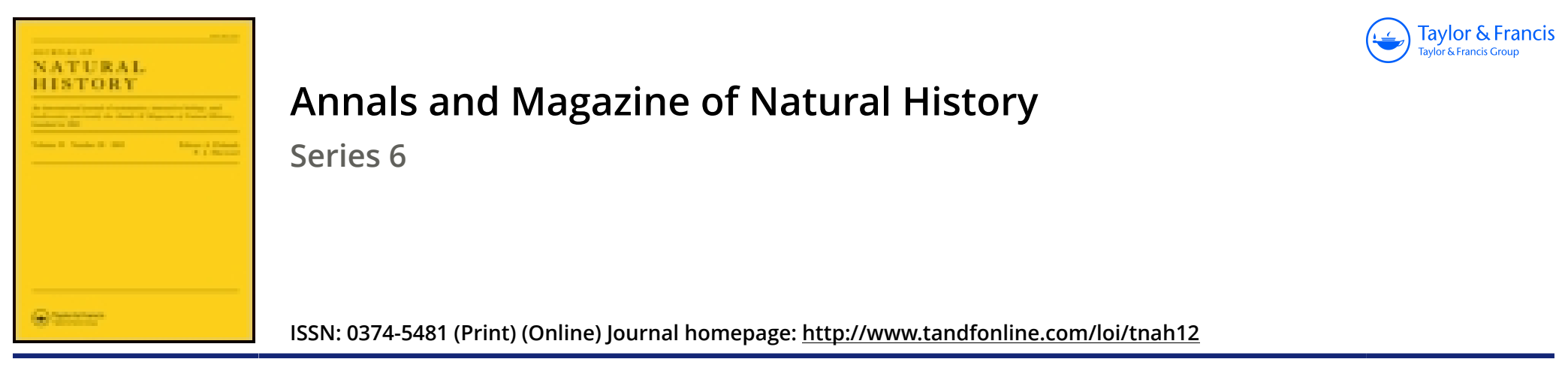

\title{
XXXIV.-On a small collection of Lepidoptera from Darwin Harbour, Falkland Islands
}

\author{
Arthur G. Butler Ph.D. F.L.S. F.Z.S.
}

To cite this article: Arthur G. Butler Ph.D. F.L.S. F.Z.S. (1893) XXXIV.-On a small collection of Lepidoptera from Darwin Harbour, Falkland Islands, Annals and Magazine of Natural History, 12:69, 207-210, DOI: 10.1080/00222939308677606

To link to this article: http://dx.doi.org/10.1080/00222939308677606

曲 Published online: 06 Oct 2009.

Submit your article to this journal $\lceil\pi$

Џ Article views: 3

Q View related articles $\asymp$ 
XXXIV.-On a small Collection of Lepidoptera from Darwin Harbour, Falkland Islands. By Ar'THUR G. BUTLER, Ph.D., F.L.S., F.Z.S., \&c.

THE little series of Lepidoptera of which the following is an account was obtained by Dr. W. F. Dale, and sent to Mr. J. Hartley Durrant, who forwarded it to me with the request that I would name it.

The collection contains ten species represented by about forty specimens, and is interesting as a contribution to a littleknown fauna. So far as I can jndge, it seems to show greater affinity to that of Chili than to any other.

\section{Argynnis siga.}

Argynnis siga, Hübner, Samml. exot. Schmett. Zutr. fgg. 677, 678 (1832).

One example.

This is the only butterfly in the collection. No Sphinges or Bombyces were obtained; indeed, the most largely represented tribe was the Noctuites.

\section{Agrotis hispidula.}

Agrotis hispidula, Guenée, Noct. i. p. 293. n. 476 (1852).

Five examples of this somewhat variable species; it was originally described from Chili.

\section{Agrotis Dalei, sp. n.}

This insect has somewhat the aspect of a Nonagria; it has, however, very coarsely spined tibiæ and the antennæ are strongly pectinated, each pecten being finely ciliated on each side. Primaries above pale sericeous buff (almost dead gold in tint); costal half sparsely, irregularly, but distinctly speckled with black; a curved discal series of similar black flecks from near costa almost to inner margin beyond the cell; a few fine scattered black dots near outer margin and a welldefined marginal series; fringe of inner and outer margins pale cupreous or rufous-brown, traversed by two grey lines: secondaries grey, slightly darker on external border; fringe buff, shading into reddish ochreous towards apex : head and collar testaceous, the face slightly yellower; antennæ ferruginous; thorax sordid pale buff; abdomen grey, with pale ferruginous lateral and anal tufts. Primaries below smoky grey, slightly blackish at base of costa ; base of median and 
submedian veins pearly opaline; costa washed with buff; an ill-defined transverse dusky discal stripe; external area pale rosy cupreous: secondaries sericeous whitish, the costal area, veins, and fringe buff, slightly rufons; a discocellular spot and five or six longitudinal dashes on the veins across the disk black: pectus whity-brown; legs rufous-brown, with ferruginous spines and whitish-tipped spurs; venter rosy, with the anal tufts slightly yellower.

Expanse of wings 43 millim.

One male of this very distinct species.

\section{Peridroma hostilis.}

Agrotis hostilis, Walker, Lep. Het. xi. p. 737 (1857).

Four examples.

I believe that this is no more than an extreme form of $P$. saucia. $P$. stictica, Blanch., from Chili, is quite intermediate in character between the two.

\section{Peridroma clerica.}

Agrotis clerica, Butler, Trans. Ent. Soc. 1882, p. 129, n. 27.

Three examples of this Chilian species.

\section{Leucania falklandica, sp. n.}

In marking somewhat intermediate between $L$. sinuosa of India and L. propria of New Zealand. Primaries above sericeous whity brown, the course of the median vein and the external border's suffused with grey; a black dot followed by a blackish spot at base of costal area; a diffused black streak, trisinuate in front, immediately above the median vein, terminating beyond the cell in a small oblique 3-shaped character; a well-defined black streak from base below the median vein, terminated by the extrabasilar line, which is much interrupted, transverse, and lunulated; a blackish dash on the inner margin also followed immediately by the same line; discal or postmedian line fine, arched inwards to costa, dentatesinuate; a slightly irregular submarginal series of blackish sagittate spots ; fringe white, traversed by two grey lines: secondaries white, slightly opalescent, the costal area silvery; veins and a rather narrow diffused external border smoky grey; fringe white, traversed internally by a smoky grey line: head and thorax whity-brown; collar greyish white, crossed at the back by an interrupted black line; tegulæ whitish at their apices; base of abdomen whitish buff, the remainder sericeous smoky greyish. Primaries below silvery 
greyish, becoming yellower on costa: secondaries white, with costa and veins buff; a diffused greyish external border; fringes as above: body below sandy buff, greyish here and there; tibial fringes slightly rufous, whitish at tips; venter sericeous.

Expanse of wings 37 millim.

\section{Eupithecia anguligera, sp. n.}

Somewhat intermediate in character between $E$. fasciata from the Nilgiris and $E$. sibylla from Chili. Leaden grey, slightly tinted here and there with brown : primaries elongatetriangular, traversed by about ten wavy blackish lines, but extremely variable; the alternate lines, beginning with that nearest the base, blacker, and therefore better defined than the others, the fifth and seventh, representing the outlines of the central band, black, thicker than the others and acutely angulated towards costa; the tenth line composed of more or less confluent pale-bordered blackish submarginal lunules; a marginal series of externally whitish-edged black dashes: secondaries with hardly a trace of marking from the median vein upwards; a triangular black patch at base below the cell, followed by six blackish zigzag lines, of which the first, third, and fifth are best defined and quite black upon the veins; marginal black dashes as on the primaries: thorax pale leaden grey, with darker transverse bands; abdomen much darker, with almost confluent blackish bands in the type, but extremely variable in depth of colour in a series. Under surface sericeous leaden grey; all the wings with black or blackish discocellular stigma, followed by two parallel blackish lines; the secondaries with traces of a third (subbasal) line; black marginal dashes as above.

Expanse of wings 19 millim.

A series of twenty-one examples, most of them more or less worn.

In some specimens the markings are very indistinct, in others the two black lines of the central band alone remain, with a well-defined discocellular stigma (which, in the type above described, is only shown on the under surface); in others again the outer line of the central band is only marked with black on the veins. In all these specimens, however, such markings as exist are similar in outline and similarly placed, so that it is evident that they represent only one variable species.

Ann. \& Mag. N. Hist. Ser, 6. Vol. xii. 
8. Scoparia?, sp.

A single example in worn condition.

9. Crambus, sp.

Three examples of a species allied to $C$. vitellus of New Zealand. The latter is also described as $C$. sublicellus, Zell.

\section{Apurima, sp.}

Three examples, in poor condition, of a species apparently referable to this genus.

XXXV.-New Species of Oriental Moths.

By Col. C. Swinhoe, M.A., F.L.S., \&c.

\section{Family Saturniidæ.}

Antheroea delegata, sp. n.

ð오. Bright ochreous red; antennæ pale red, front of thorax and costal band of fore wings dark steel-grey, the band in the male not reaching the apex, the ocelli in the male narrow, in the female large and round, ringed with brown, interlined with pale yellow and bordered by a black line, which runs inwards on each side of the ring and meets on the costa in the male only; the inner portion of both wings is covered with yellow patches, which are bright ochreous in the female, a prominent triangular patch being in the cell towards the base; two outwardly angulated, discal, thin, brown bands across both wings, close together, the outer one edged outwardly with grey, the space from this band to the outer margin dark uniform ochreous red; a yellow subcostal streak on fore wings near apex, with a deep black streak; a steel-grey band on both wings close to the outer margin.

Expanse of wings, o $6 \frac{2}{10}$, $q 6 \frac{9}{10}$ inches.

Singapore (Davison). One pair.

The markings above are somewhat as in A. Frithi, Moore, but in this species both sexes are similarly coloured and marked, and in the male the hyaline discal ocelli are narrow, and not round, as in that sex of Frithi; this species is also allied to A. latissa, Westw., from Java. 